\title{
ANALYSIS OF SWIMMING POOL ACCIDENTS RESULTING IN SPINAL CORD INJURY ${ }^{1}$
}

\author{
By Barth A. Green, M.D., ${ }^{2}$ M. Alexander Gabrielsen, Ph.D., ${ }^{3}$ Wiley J. Hall, B.S. ${ }^{4}$ \\ and JAMES O'HEIR ${ }^{5}$ \\ ${ }^{2}$ Acute Spinal Cord Injury, South Florida Regional Spinal Cord Injury System; ${ }^{3}$ Director, \\ Studies in Human Habitability, Nova University, Fort Lauderdale, Florida; ${ }^{4}$ Department \\ of Orthopaedic Surgery, University of Southern California, Los Angeles, California; \\ ${ }^{5}$ Emergency Medical Services, University of Miami, Miami, Florida
}

Key words: Spinal Cord Injury; Swimming pool; diving; negligence; rescue equipment

\section{Introduction}

THE National Electronics Injury Surveillance System (NEISS) reported an estimated 65000 pool-related accidents occur in the United States annually. With the exception of death, acute spinal cord injury represents the most catastrophic result of these accidents with regard to morbidity, and in terma of permanent disability and cost. It has been adequately documented that optimal care of the spinal cord injury patient occurs with the greatest consistency within a comprehensive spinal cord injury system. Unfortunately, these centres are few in number and far between in location. In the United States at present, there are 13 federally designated Model System programmes. Additionally, I9 Veterans Administration Hospitals provide spinal cord injury centre care. Other centres operate without official designation. However, at present, there is no nationally organised care system providing comprehensive, specialised care to all patients who have suffered these devastating injuries. Additionally, across the country there is a great disparity regarding the delivery of pre-hospital care. In many areas, pre-hospital care has attained a high level of sophistication with stratification of personnel and identification and designation of emergency care centres, both general and specialised. Efforts are on-going at local, state and federal levels to guarantee the availability of spinal cord injury centre care and concurrently upgrade pre-hospital care where necessary.

\section{Method}

This study involved the analysis of 50 retrospective and 22 prospective swimming-pool accident cases. The retrospective cases were defined as accidents occurring prior to I January I 976 and were studied because extensive records were available due to the completion of both the acute and rehabilitative phases of treatment for these patients. The prospective cases were examined so that

Correspondence. Barth A. Green, M.D., Chief, Acute Spinal Cord Injury, University of Miami, School of Medicine, Department of Neurological Surgery (D4-6), P.O. Box or6960, Miami, Florida 33I0I.

1 This work is supported in part by the Rehabilitative Services Administration \#13-P-59258/4-OI. 
information could be collected within hours of the occurrence and provide a more detailed accident scene analysis while the associated circumstances were fresh in the minds of victims and witnesses. In the majority of cases, the scene was visited by team members, and photographed and analysed in terms of environmental factors relating to the event. The victims, witnesses and involved porfessional and para-professional personnel were interviewed and all available records were reviewed in detail. In many cases, active litigation presented a barrier to release of information. Each case report consisted of a narrative summary of the events preceding the accident, human factors related to the incident, pool and equipment data, medical analysis and observations and recommendations.

\section{Results}

Sixty-four of the 72 cases reviewed resulted in spinal cord injury, and 57 were determined to be quadriplegics (Table I). The distribution of the skeletal and

\section{TABLE I}

Type of injuries

\begin{tabular}{|c|c|c|}
\hline A. & Tetraplegic & 57 \\
\hline B. & Skull fracture and lacerations & 2 \\
\hline C. & Permanent brain damage & 3 \\
\hline D. & Broken arm and damaged shoulder & I \\
\hline E. & $\begin{array}{l}\text { Mid-dorsal vertebrae compression } \\
\text { fracture }\end{array}$ & I \\
\hline F. & $\begin{array}{l}\text { Fracture of vertebrae with no } \\
\text { permanent damage }\end{array}$ & 4 \\
\hline G. & $\begin{array}{l}\text { Fracture of neck with some } \\
\text { neurological deficiency }\end{array}$ & 2 \\
\hline H. & Permanent internal injuries & I \\
\hline I. & Minor injury & I \\
\hline
\end{tabular}

neurological levels of injury correlate with previously reported data (Table II). The majority of the injuries occurred in the mid to low cervical levels, a region recognised as exhibiting the greatest mobility of any portion of the spinal column and therefore most susceptible to such injuries. The primary cause of injury was diving into shallow water with a significant number being associated with waterslides. Surprisingly, only 5 accidents resulted from unintentional acts, such as falls (Table III). In 75 per cent of the cases, Emergency Medical Services personnel responded within Io min of notification. It was distressing to note that in 59 cases, the victims were removed from the pool improperly, considering the nature of their injury.

Approximately one-third of the patients arrived at the first medical facility within I $5 \mathrm{~min}$. In excess of one-third of the patients were treated at more than three hospitals during their acute care phase. It was obvious from the medical analyses of the treatment records that the length of hospitalisation and the type of management differed drastically in most cases. There was little similarity of treatment programmes, either surgically or non-surgically, between the various physicians, hospitals and centres in managing these acute injuries. Twenty-seven 


\section{TABLE II}

Level of injuries

\begin{tabular}{lcc}
\hline Level & Skeletal & Neurological \\
\hline CI & $-0-$ & I \\
CI-2 & 2 & $-0-$ \\
C2-3 & I & $-0-$ \\
C2-3-4 & I & $-0-$ \\
C3-4 & I & $-0-$ \\
C4 & I & 3 \\
C4-5 & 8 & I \\
C4-5-6 & I & I \\
C5 & I5 & I6 \\
C5-6 & I2 & 4 \\
C5-7 & I & $-0-$ \\
C6 & 6 & I9 \\
C6-7 & 7 & I \\
C7 & I & I \\
C8-T & $-0-$ & I \\
T4, 5, 6, 7, 8, 9 & I & $-0-$ \\
T6 & I & I \\
None & 2 & 6 \\
& 6I & 68
\end{tabular}

The number of spinal cord injuries by bony and neurological level. There was no correlation between the skeletal level and neurological function in the table.

of the patients were admitted to a spinal cord injury centre within I day of the injury, which must be regarded as a positive factor when considering the small number of such facilities available in this country.

Analysis of the personal characteristics of the victims was consistent with demographic data reported previously, i.e., the majority being young, caucasian males. By height and weight, they fall into a category which is slightly larger than average, perhaps because the majority of these injuries seem to occur in more athletically inclined or physically active individuals. There were no special trends regarding the day of the week or the particular hour of occurrence, with the exception that most of the injuries occurred during the afternoon or evening. The peak time of occurrence was different, however, from the National Registry report by Ducker, which indicated that most spinal cord injuries occurred between midnight and 5 a.m.

It was interesting to note that 37 of the patients received no formal swimming or diving instructions, most claiming to be self-taught or trained by relatives or friends. Additionally, 46 of the patients had little or no familiarisation with the pool in which they were injured. There have been numerous reports of alcohol and/or drugs associated with spinal cord injuries as with other forms of trauma; however, in this study few of the victims had consumed alcohol and in only one case was there suspicion of drug ingestion.

Sixty-nine of the 72 victims received no verbal or written warnings of the dangers related to pool activities. Fifty-five of the patients were extricated from the pool by persons with no training in rescue techniques. Improper extrication 


\section{TABLE III}

Activity associated with accident

A. Diving

I. Dive into shallow portion ( 4 feet or less of an in-ground pool containing variable depth

2. Dive into an above-ground constant depth vinyl linear pool of 4 feet or less from attached platform, deck, coping of pool, or ladder

3. Dive into an above-ground vinyl pool with variable depth into shallow end from deck or attached platform

4. Dive from springboard 30 inches or less from water

5. Dive from I-metre springboard

6. Dive from 3-metre springboard

7. Dive from pool's internal steps

8. A cannonball dive into shallow portion of pool

9. Dive from deck of pool into deep or hopper bottom pool

Io. Struck springboard while executing dive from I-metre board

II. Struck end wall of pool while diving from I-metre board

12. Dive from deck into water $5 \frac{1}{2}$ feet deep

13. Struck up-slope of bottom from dive of 3 -feet high springboard

I4. Dive from roof of house and balcony of apartment house

B. Water Slide

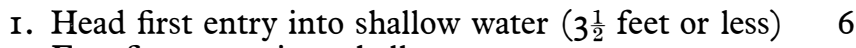

2. Feet first entry into shallow water

3. Dive from top of slide into shallow water

C. Others

I. Fell into pool

2. Struck internal steps while swimming underwater

3. Slipped on deck of pool and struck coping

4. High school physical education swimming class

5. Attempting rescue of another swimmer

6. Fell from ladder of 3-metre diving stand

7. Got stuck in bottom drain of pool

is frequently associated with secondary spinal cord injuries and it has been the unhappy experience of the authors that victims of diving accidents have reported initial motor function after impact but after being pulled over pool edges, rolled over or manipulated improperly, have lost this capability. In 54 of the cases, there was no person designated as responsible for the pool area present at the time of injury.

The human factor appeared to be a very important consideration in these injuries. A subjective analysis of the information related to each accident 
indicated that 54 cases involved an element of contributory negligence on the part of the victim. In addition, pool design and owner failure to take appropriate precautionary measures contributed to many of the accidents. The personal characteristics of the injured persons are presented in Table IV. Commonly used national figures show an estimated $4:$ I ratio of male to female. In this study that ratio was much higher with 64 of 72 cases involving males. It was also of interest

\section{TABLE IV}

Personal characteristics of injured persons

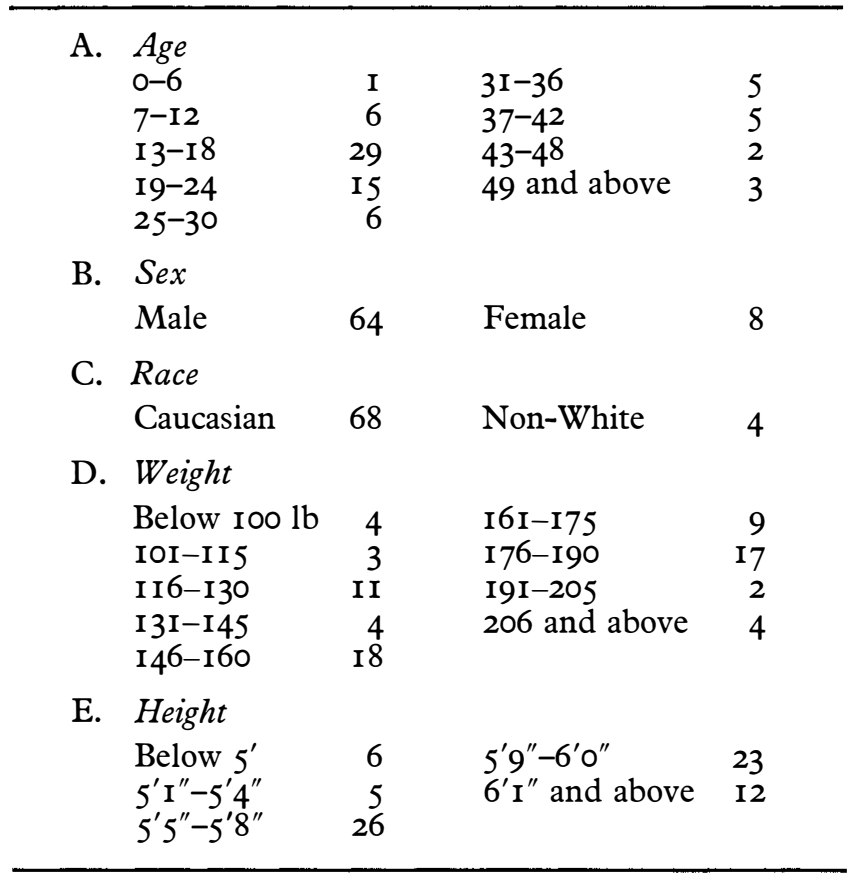

that 6I per cent of the victims were in the 13-24 age group, which coincides with the range generally reported as at highest risk for spinal cord injury.

Forty incidents occurred in residential pools, Io in hotels/motels, 40 in apartment complexes, I in a commercial pool, 6 in public pools i.e., school or park, and 2 in private clubs. One-third of the pools were of the above-ground type and approximately one-half had vinyl liners which were reported by the victims as slippery and related to the cause of the injury. Fifty-one of the accidents occurred in less than 4 feet of water, perhaps because 46 of the pools did not have depth markings and only $\mathrm{I} 3 \mathrm{had}$ visual markings on the bottom of the pool. In addition, 22 of the injuries occurred when lighting was a factor due to the time of accident. In 5 of these cases the lighting was considered inadequate. Finally, there were no safety rules posted in 43 of the pools.

Following the accidents rescue efforts were hampered by additional lack of regard for safety measures. The majority of the pools did not have rescue equipment within a reasonable distance at the time of the injury, and only 28 had rescue equipment in a fixed position. Furthermore, only 20 of the sites had a telephone 
available in the pool area. Table $\mathrm{V}$ reflects those factors considered by the engineering group as contributing to many of the injuries.

\section{TABLE V}

Pool factors contributing to accident

\begin{tabular}{llr}
\hline A. Shallow water (5 feet or less) & 52 \\
B. Improper installation of equipment & 8 \\
C. Slippery condition of pool's bottom & 2 I \\
D. Absence of bottom markings & 43 \\
E. Absence of depth markings & 35 \\
F. No warning signs & 45 \\
G. Inadequate depth of water for springboard diving & 9 \\
H. Inadequate lighting for night swimming & 9 \\
I. Water level had been lowered ro to I2 inches & I \\
J. No fence around pool & I \\
K. Inadequate water depth under water slide & 7 \\
L. Slippery deck condition & I \\
M. Slippery condition of surface of springboard & I \\
N. Improper design creating unsuspecting drop-o? & I \\
O. Slippery coping & I \\
P. Slippery steps on diving stand (3 metres) & I \\
Q. Unsecured bottom drain cover & I \\
R. Signs not readable to foreigner & I \\
S. Not applicable & I \\
\hline
\end{tabular}

Note. In many situations there is more than one factor which may have been related to the accident.

\section{Discussion}

The review of these 72 cases revealed several interesting facts. There were appreciable differences between the data available from the retrospective and prospective cases. Surprisingly, the prospective patients were more difficult to interview and collect data from because of their medical condition and hesitancy on the part of the family and legal advisors to allow investigation (even when confidentiality was assured). The typical patient profile in the group was that of a caucasian male, athletically inclined without pre-existing medical problems, in the age group I 3 to 24 who sustained cervical fractures as a result of striking the bottom of the pool with their heads. A conclusion one may draw from this study is that some of these patients may have suffered secondary spinal cord injury due to mishandling at the accident scene or during the acute phase of their care. These factors may be related to insufficient national public education effort regarding identification and pre-hospital management of this type of accident as well as public education programmes aimed at prevention of such injuries. Also of note were the delays of weeks or months before many of the victims were referred to Spinal Cord Injury Centres. This is in spite of the many studies demonstrating the effectiveness of such centres in reducing morbidity, mortality and cost of care.

In the 3 to 4 years since the injuries reviewed have occurred, there has been a significant national trend towards utilisation and expansion of spinal cord injury system care. Such systems include programmes for prevention, pre-hospital emergency medical services, acute in-hospital care, rehabilitation, and life-long 
follow-up. This trend has been spearheaded by the Regional Spinal Cord Injury Care Systems and Veterans Administration Spinal Cord Injury Centre Programmes.

\section{SUMMARY}

This paper is a summary of a study of 72 cases of swimming-pool accidents resulting in serious injuries with the potential of permanent disability. Sixty-four of the 72 cases resulted in spinal cord injuries, 57 of which involved quadriplegic lesions. The authors observed that the majority of these injuries resulted from a lack of good judgement and common sense rather than from intoxication or pool structural deficiencies. Also of note was the lack of appropriate first-aid and extrication rendered, as well as the absence of uniform treatment and care received by the majority of the patients.

\section{RÉSUMÉ}

Il s'agit d'une étude portant sur 72 accidents de piscine avec séquelles graves, dont 66 dues à des lésions de la moelle épinière, 57 d'entre elles dans la région cervicale. La majorité des lésions cervicales se sont produites dans la partie moyenne et basse de la moelle cervicale. La cause principale des accidents était la plongée en eau peu profonde, quelques unes associées avec des toboggans. Seulement 5 accidents étaient dûs à des chutes non intentionnelles. Dans $75 \%$ des cas, les secours d'urgence avaient été donnés dans les ro premières minutes. 59 blessés ont été retirés de la piscine d'une manière incorrecte. 27 blessés ont été admis dans un service spécialisés dans les premières 24 heures après l'accident, ce qui doit être considéré comme un facteur positif si l'on considère les Etats-Unis. La plupart des accidents se sont produits au cours de l'après-midi et de la soirée, sans aucune incidence particulière du jour. 37 des blessés n'avaient jamais reçu de leçon de natation ni instructions de plongée, 46 n'étaient pas familiers avec la piscine dans laquelle l'accident a eu lieu. La consommation d'alcool n'était pas élevée, seulement dans un cas les auteurs ont pu suspecter l'injestion de drogue. Dans 69 cas sur 72, il n'y avait pas d'avertissement en ce qui concerne les dangers, 5.5 patients ont été retirés de l'eau par des personnes ne connaissant pas les techniques de sauvetage. Des aggravations ont été notées au moment où les personnes ont été retirées de la piscine. 5I des accidents se son produits à moins de Im2o de profondeur. Les auteurs sont très découragés par le délai en semaines ou mois avant que les victimes ne soient transférés dans un établissement spécialisé.

\section{ZUSAMMENFASSUNG}

Diese Arbeit ist eine Zusammenfassung einer Studie von 72 Schwimmbadunfällen, die in ernstlichen Verletzungen mit der Möglichkeit für eine dauernde Arbeitsunfähigkeit resultierten. Vierundsechzig von den 72 Fällen resultierten in Rückenmarksverletzungen, von denen 57 Querschnittsverletzungen im Halsbereich waren. Die Authoren waren bestürzt über die Feststellung, dass die Mehrheit dieser Verletzugen eher dem Fehlen von gutem Urteilsvermögen und gesundem Menschenverstand zuzuschreiben waren, als Alcohol Intoxication oder mangelhaften Schwimmbadinstruktion. Wir waren ebenso alarmiert über über das Fehlen von entsprechender Erster Hilfe und den Methoden der unmittelbaren Rettung aus dem Wasser, sowie auch dem Fehlen von einer gleichmässigen Sorgfalt in der Behandlung, die die Mehrheit dieser Patienten erhalten hatte.

Acknowledgement. The study was conducted for the United States Consumer Products Safety Commission, Washington, D.C. 